\title{
ОТВЕТСТВЕННОСТЬ ЭЛИТЫ
}

\author{
А.И. Подберёзкин
}

$\mathrm{H}$ еобходимо, на мой взгляд, акцентировать внимание на прикладном характере нынешней дискуссии. Она имеет колоссальное значение не только для философов, но и для людей, занятых решением конкретных проблем. К счастью, у нас уже признаётся прикладная значимость этих проблем, но выводов окончательных еще не сделано. В частности, в последнем послании Путина об этом говорилось, идёт большая дискуссия в СМИ, особенно в неолиберальных. Например, это выходит на поверхность в дискуссиях о роли религии.

Для политиков прежде всего важно понять, что произошли радикальные изменения в общественном сознании, которые еще не нашли своё отражение ни в учебниках, ни в других публикациях. А именно резко произошло смещение акцентов в политике на ценностные аспекты. В частности, если взять Евросоюз, там идёт острая борьба не столько за национальные интересы стран-членов ЕС, сколько за продвижение, иногда силовое, систем ценностей. Если вы этот процесс заметили, тогда становится понятна и та коллизия, которая произошла на Украине.

Строго говоря, стоит вопрос, что нужно Евросоюзу и НАТО от Украины? Понятно, что Украина как член НАТО им не нужна. Понятно, что и как член Евросоюза она им не нужна. Возникает вопрос: а какая цель преследуется ЕС и НАТО в отношении Украины? А цель очень простая. Им важно не допустить, чтобы она стала членом другого, нового формирующегося центра силы, в основе которого лежит другая система ценностей.

Хотим мы этого или нет, но сегодня есть три доминирующие системы ценностей. В одной из своих работ А. В. Шестопал писал об этом. Прежде всего, это евро-атлантическая либеральная система ценностей. На Западе этого не скрывают и силовым образом навязывают. Безусловно, есть китайская, конфуцианско-социалистическая система. Есть и индийская, правда, Индия сейчас затаилась. Но это не значит, что она не будет проводить активную внешнюю политику через пять-десять лет, когда её потенциал будет сопоставим с ведущими мировыми державами.

Если понять это фундаментальное изменение: перенос ценностных противоречий в политическую сферу, даже вытеснение классической борьбы государственных интересов, то оно становится очень важным для практических задач. Мы, например, сейчас работаем над важной темой, возникшей из поручения Президента Генштабу по-новому оценить характер внешних военных угроз. Это суперважная тема, потому что в зависимости от их оценки формируются отношения внутри и вовне России. Таким образом, это не просто полезные философские размышления, а сугубо прагматические вещи.

Сейчас, когда мы работаем над этим заказом (в частности, в нём речь идет о военной доктрине), я обнаружил, что военная доктрина как система взглядов общества претерпела серьёзные изменения под влиянием процесса изменения ценностных аспектов. Например, мы сейчас уже не можем говорить только о военной доктрине государства, мы должны говорить о военной доктрине нации. Я обозначу эту проблему тезисно, потому что говорить можно очень долго. Разница между государством и нацией понятна. Государство - это институт. Нация - более широкое понятие. Государство не всегда действует в интересах нации, поэтому между ними нельзя ставить знак равенства. Военная доктрина нации отличается от военной доктрины государства, в том числе в ценностном и нормативном планах. Сейчас, например, военная доктрина государства утверждается указом президента, как и все другие нормативные документы - концепция внешней политики, стратегия национальной безопасности, военно-морская доктрина и т.п.

Национальную доктрину необходимо принимать хотя бы на уровне Федерального закона, потому что нормативные документы вообще никем не исполняются - в этом наша беда. Принимается нормативный документ, а потом даже при подготовке другого нормативного документа о нём забывают. Следующая особенность, ко- 
торая вытекает из этого ценностного изменения: эти нормативные документы должны по-новому формироваться, по-новому утверждаться, быть коллективными, так как даже те документы, которые были приняты недавно и были ориентированы на государство, уже устарели. Очень важный момент, что все эти документы и все эти стратегии должны по-новому обсуждаться. Если это национальный документ, имеющий ценностное значение, он должен обсуждаться и в политической элите, и в обществе, что нигде и никогда не делалось. Вы где-нибудь видели телеобсуждение концепции внешней политики России? Нет. Я, например, участвовал, писал свои предложения, но это на закрытом, экспертном уровне. А в принципе общество в этом не принимало участия. Политики не принимали в этом участия. Никогда это широко не обсуждалось и на экспертном уровне: кого попросили, те дали свои предложения. А те, кого не попросили, но кто хотел бы выступить, остались за скобками.

Это имеет колоссальное значение, потому что главной целью враждебной политики является уничтожение не государств, а наций. В этом принципиальное отличие. Помните классическое определение военной силы: она нужна для того, чтобы добиться силовыми средствами каких-то политических целей. Какие были политические цели? Оккупировать территорию, навязать какие-то новые условия по какому-то мирному договору. Зафиксировать новые отношения.

Сейчас не стоит задача оккупировать территорию. Если я навязываю вам свою систему ценностей, свою систему управления, то ничего не надо больше делать. Вы выполняйте просто то, что мне нужно. В общественной и политической жизни будет происходить то, что сейчас наблюдается, - навязывание мультикультурализм, десекуляризация, пресловутое отношение к полам и т.д. Из этого следуют очень важные выводы. У государства есть сухопутные войска, военно-морские силы, авиация и т.д. А сейчас появляются новые средства вооружённой борьбы. В строгом смысле слова они к вооружённым силам не относятся, но они имеют колоссальное значение. На последнем заседании ОДКБ прямо говорилось об отношении к информационным средствам воздействия, если целью их является уничтожение системы ценностей и политического руководства. Это были не военные средства. Но вначале американцы, а потом и мы создали киберкомандование. Правда, у нас и у них пока нет войск, но командование, начальники уже есть. У них, правда, больше, чем у нас, раз в десять. Но в строгом смысле слова это не вооружённые силы. Вирус, который запускается в программное обеспечение и нарушает систему управления, это не военное средство. Но это силовое средство. И значение таких средств возрастает.

Всё это можно представить в виде схемы. Представьте себе, что в левой стороне доски
20 лет назад было некое соотношение силовых военных средств и силовых невоенных средств, где-то 10:1. Силовые военные средства - танки, пушки, вооружённые силы - имели колоссальное значение в сравнении с такими невоенными средствами, как радио и пропаганда. Примерно в соотношении 1:10, 1:20. Сейчас соотношение изменилось в пользу силовых, но не военных средств. Каждые пять лет это соотношение менялось и в настоящее время составляет 60:40 в пользу невоенных средств насилия. По сути дела, война начинается не тогда, когда начинаются бомбардировки, а гораздо раньше. В 1998 г. я был в штаб-квартире НАТО накануне начала бомбардировок Югославии. Тогда не было никакого решения ни ООН, ни даже НАТО, но уже был создан комитет по информационнопсихологической подготовке. Шесть месяцев он готовил общественное мнение, дезорганизовывал общественное мнение в Югославии для того, чтобы потом осуществить военную операцию.

Очень большое значение имеет взаимосвязь изменения системы ценностей и человеческого капитала. Что сейчас становится главным для ведения эффективной вооружённой борьбы? Совершенно определённо - человек. Это значение стремительно возрастает. Например, у нас появилась новая идея фикс создать авианосноударные группировки. На мой взгляд, идея совершенно бредовая. Построить огромный авианосец стоит несколько миллиардов долларов. Кроме того - корабли сопровождения, потому что авианосцы сами не ходят. Нужна также инфраструктура на побережье и т.д. Но не это главное. У нас нет соответствующих самолётов. Те, которые есть, мало приспособлены для палубных взлётов и посадок. Но основное - нет пилотов. Подготовка одного пилота палубной авиации занимает уже не 5, а 10 лет. Просто лётчика готовить нужно 5 лет. Обычный лётчик, который окончил военное училище и два года полетал после него, старший лейтенант, не видит боевого пространства, не реагирует на внешние угрозы. Его надо натаскивать и натаскивать. А лётчика палубной авиации надо готовить 10-15 лет. Их у нас в пять раз меньше, чем космонавтов. И как их готовить, мы не знаем. Если одиндва авианосца за пять лет ещё как-то можно построить, то лётчиков точно подготовить не успеют. И вообще всё это очень дорого стоит.

Любой человек, профессионал, знает, что мозги стоят очень дорого. Например, подготовка лётчика стоит 5 млн долл., лётчика палубной авиации - 15-20 млн долл. А у нас получается так: человек пришёл, послужил, набрался опыта, а от него затем избавляются. Американцы прямо объявили, что идёт борьба за человеческие ресурсы. Зачем тратить 15-20 млн на подготовку человека, когда я могу купить его за 50 тыс., готовенького, со всеми его библиотеками, наработками и т.п.

Всё это имеет колоссальное значение. Потому что военная эффективность зависит и 
от качества командного состава. Меня всегда интересовал первый период Второй мировой войны. Я говорил с военными. Действительно, соотношение танков и авиации был в нашу пользу. По численности личного состава - тоже в пользу СССР. Вопрос у меня всегда возникал один и тот же к ветеранам, к военным учёным: почему в первые месяцы мы терпели поражение? Были уничтожены почти все наши танки, авиация и т.п. Ответ на самом деле очень простой - качество личного состава. У нас любой человек, который окончил среднюю школу, в то время считался уже с высшим образованием. И назначался, условно говоря, командиром взвода. А его солдатики все были неграмотные, неподготовленные. Такие же были и командиры. Когда они кровью своей научились к 1943 г. воевать, тогда у нас появилась профессиональная армия. Людей готовили в ходе боёв. В итоге ответ очень простой: качество личного состава уже тогда играло роль. А сейчас его значение возросло.

Возьмём последнюю операцию американцев в Ираке. Количество танков с обеих сторон было примерно одинаковым. А потери были в тридцать раз больше у иракских танкистов, которые сидели в наших, кстати сказать, неплохих танках. Ясно, что значение качества подготовки личного состава - от рядового до генерала - стало решающим. Речь идёт о качестве человеческого капитала. Следующий момент - качество вооружений и военной техники. Что происходит сейчас? Раньше какая-то система или вид оружия менялся каждые два - четыре года. Сколько у нас было модернизаций танков, авиации? Кстати сказать, американский бомбардировщик Б 52 последний раз был выпущен в 1960 г., но до сих пор летает. Ему лётный срок ещё на 20 лет продлили. Новые системы оружия сегодня создаются 20-25 лет, долго испытываются, модернизируются, но долго и служат. Те системы оружия, которые сейчас создаются, уже испытываются, будут служить ещё лет 30-50. Но они страшно дорогие. Один самолёт пятого поколения стоит в 10 раз дороже, чем четвёртого. Это целая новая авиационная система.

Какое это имеет отношение к системе традиционных ценностей? Да самое прямое, прагматическое. Наша модернизация, политика инноваций основана на ложной концепции внешних заимствований. А эти заимствования могут в лучшем случае повторить, да и то с опозданием, то, что было сделано за рубежом. Особенно это касается военных изделий. Вам не продадут современный танк, вам продадут танк, который был произведён 20 лет назад. И в технологиях то же самое. Вам не дадут современную технологию. А нам нужна не просто самая современная техника, нам нужна та, которой ещё нет. А её способны создать только национальные научные школы. Опять же всё упирается в человека. До революции на дверях квартир писали, например, «инженер Иванов». А какое отношение формировалось к инженерам, к научному потенциалу последние десятилетия советской власти и в наши дни, когда кандидаты и доктора наук вынуждены торговать на рынках? В итоге развалились многие национальные научные школы. Конкретные примеры: фактически уничтожили Академию химзащиты, перевели её в другой город. Если перевести в другой город МГИМО, куда-нибудь под Подольск, я сомневаюсь, что туда кто-нибудь из профессуры поедет, найдут другие места работы. Так получилось с Академией химзащиты. Вопрос: случись, упаси Господи, ещё один Чернобыль -кто будет этим вопросом заниматься?

Уничтожили целую научную школу, точнее, целые научные школы. Уничтожить школу можно быстро, что у нас и происходило. Восстановить её требуются десятилетия. В общем, создаются школы десятилетиями, и только на национальной основе. Точно так же - конструкторские школы. Сейчас возникла проблема: деньги на оборонку есть, а специалистов нет. Пока ещё спасают ситуацию «лыжники»: директора институтов, конструкторы, которым под 80 лет. Их так называют потому, что они ходят, шаркая ногами. Что будет дальше? Молодых-то нет. Ситуация с человеческим капиталом имеет принципиальное значение. В нашей системе ценностей новые продукты и смыслы мы сможем создавать только на основе национальных научных школ. Некоторые у нас думают, что мы купим за рубежом, привлечём неких бизнесменов (которые никогда не будут инвестировать в фундаментальную науку) и потом что-то из этого получится. Сейчас ситуация стала меняться, но недостаточно быстро. Потому что сейчас мы тратим на науку значительно меньше, чем развитые страны.

Нужны кардинальные перемены. Пока что происходит то, что Путин назвал попыткой частными решениями компенсировать провал 1990 - 2000-х гг. Все опасаются, что деньги на оборону опять разворуют. Конечно, разворуют. Потому что деньги, которые сейчас дают, не подчинённые контролю и управлению, очень часто используются нецелевым образом. Поэтому придумывают разные программы, фонды в надежде на то, что это спасёт ситуацию. Но хорошо, что хоть в этом направлении мыслить начали.

Podberjoskin A.I. Responsibility of elite. 